\title{
Rice Farming Feasibility Using Subsidized And Non-Subsidized Rice Seeds In Sekar Putih Village, Widodaren District, Ngawi District, East Java, Indonesia
}

\author{
Pujastuti \\ Department of Agribusiness \\ Universitas Muhammadiyah Yogyakarta \\ Yogyakarta, Indonesia \\ pujastuti@umy.ac.id
}

\author{
Lestari Rahayu \\ Department of Agribusiness \\ Universitas Muhammadiyah Yogyakarta \\ Yogyakarta, Indonesia \\ lestari_rahayu@yahoo.com
}

\author{
Arien Sisca Maharani \\ Department of Agribusiness \\ Universitas Muhammadiyah Yogyakarta \\ Yogyakarta, Indonesia \\ arien.sisca2508@gmail.com
}

\begin{abstract}
Rice is a food crop that is widely cultivated in Sekarputih Village. Farmers use more non-subsidized rice seeds. This study aims to determine the costs, income, profits and feasibility of non-subsidized and subsidized rice farming in Sekar Putih Village, Widodaren District, Ngawi District, East Java, Indonesia. The location was selected by way of purposive sampling and respondents using simple random sampling of 60 respondents. The basic method used in this research is a descriptive analysis. The results of this study the costs incurred by non-subsidized farmers are $\mathbf{R p} \mathbf{1 6 , 2 8 8 , 8 1 4}$ and subsidized of $R p$ 14.714318. Non-subsidized seed income of $R p 18,688,329$ and a subsidy of $R p 16,341,158$. Benefit of non-subsidized seeds is $R p 11,382,335$ and a subsidy is $R p$ $9,990,015$. The value of $R$ / $C$ on non-subsidized seed farming is 1.70 and 1.68 subsidized. Capital productivity in nonsubsidized seeds is $129.71 \%$ and subsidized are $122.11 \%$. Productivity of non-subsidized seed land was Rp 17,630,000 / Ha and a subsidy was Rp 15,530,000 / Ha. Non-subsidized seed labor productivity of Rp 680,407 / HKO and a subsidy of Rp 950,386 / HKO. So, it can be concluded that from the R/ C and productivity of rice farming using non-subsidized seeds is more feasible to cultivate.
\end{abstract}

Keywords—rice seeds, non-subsidized, subsidized, feasibility

\section{INTRODUCTION}

A population surge in Indonesia consequently leads to the skyrocketing national food demand including rice. On this basis, the government has come to an agreement with Vietnam, Thailand, China, India, Pakistan, the United States, Singapore and Myanmar (BPS). It is notable that the data of Indonesian rice import rice in 2013, 2014 and 2015 respectively amounted to $472,664.7$ tons; $844,163.7$ tons; and 861,601 tons. To overcome the problem of food scarcity, the government has tried to increase production in the country including by way of providing subsidized rice seeds to farmers, which may ease cultivation.

One of the areas to receive this assistance program is Ngawi Regency, East Java. Therefore, the study was conducted in Sekarputih Village, Widodaren District, Ngawi Regency as one of the rice centers in East Java, which annually produces 800 thousand tons of rice on the average. Seed assistance was provided by the regional government of Ngawi to the community in the region amounted to 2,250 tons in 2016. The seeds were subsidized at a price of $\mathrm{Rp}$
3,000, - $/ \mathrm{kg}$, while the non-subsidized price was $\mathrm{Rp} 12,000$ $/ \mathrm{kg}$.

Farmers in Ngawi District use subsidized rice seeds, but they also use more non-subsidized seeds. Farming using non-subsidized rice seeds will generate income by using subsidized seeds. Thus, it is necessary to examine the component of costs, production, and benefits for better cultivation.

This study aims to determine the costs, production, income, and profits of rice farming by using subsidized and non-subsidized rice seeds, and to know the feasibility of rice farming with subsidized and non-subsidized seeds in Sekarputih Village, Widodaren District, Ngawi Regency. It is expected that this study will be referred by the government for policy making, especially in the policy of subsidizing rice seeds.

\section{METHODS}

The basic method used this study is the descriptive analysis method. The research location was determined intentionally in Sekarputih Village given the consideration that the village was the second largest rice producer in the District of Widodaren, Ngawi Regency. The respondent's sample was done by way of simple random sampling without regard to the strata in the population [1]. The respondents in this study were 60 farmers consisting of 12 farmers using subsidized rice seeds and 48 farmers using non-subsidized seeds of the rice farming community in Sekarputih Village.

Primary data were derived from interviews using questionnaires or questionnaires commonly carried out by researchers [2], while secondary data were derived from data on the general state of the region, the state of agriculture, population conditions, topography and geographical location of the population. Feasibility analysis was conducted using capital productivity, and labor productivity.

\section{RESULTS AND DISCUSSION}

The price of subsidized seeds is cheaper because they are subsidized by the government. Farmers who use nonsubsidized seeds are greater than those who use subsidized seed, because the costs incurred for seed costs are greater. The use of fertilizers can increase crop yields if they are used optimally based on the needs of existing plants and nutrients 
[3]. Farmers opted to use more non-subsidized seeds due to refining activities. The costs used by farmers who use subsidized or non-subsidized seeds are presented in Table 1.

Table 1. The Use of fertilizer on rice farming with nonsubsidized and subsidized seed per 1 hectar

\begin{tabular}{crrrr}
\hline \multirow{2}{*}{ Description } & \multicolumn{2}{c}{ Non-Subsidized } & \multicolumn{2}{c}{ Subsidized } \\
\cline { 2 - 5 } & $\begin{array}{r}\text { Amount } \\
(\mathbf{K g})\end{array}$ & $\begin{array}{r}\text { Value } \\
(\mathbf{R p})\end{array}$ & $\begin{array}{r}\text { Amount } \\
(\mathbf{K g})\end{array}$ & $\begin{array}{r}\text { Value } \\
(\mathbf{R p})\end{array}$ \\
\hline Phonska & 392.79 & 981,965 & 486.00 & $1,215,007$ \\
SP 36 & 99.57 & 219,056 & 109.31 & 240,472 \\
Urea & 367.50 & 808,499 & 271.84 & 598,040 \\
Za & 193.30 & 309,277 & 170.71 & 273,143 \\
\hline Amount & & $\mathbf{2 , 3 1 8 , 7 9 7}$ & & $\mathbf{2 , 3 2 6 , 6 6 2}$ \\
\hline
\end{tabular}

Phonska fertilizer is most widely used by farmers making it the most expensive one. Fertilizer costs used by farmers who use subsidized or non-subsidized seeds are not much different.

Pesticides are used to overcome and eradicate pests and diseases in plants in rice farming. The use of pesticides in farming for both non-subsidized seeds and subsidized seeds can be seen in Table 2 .

Table 2. Pesticide use in rice farming with non-subsidized and subsidized seed per 1 hectar

\begin{tabular}{lrrrr}
\hline \multirow{2}{*}{ Description } & \multicolumn{2}{c}{ Non-subsidized } & \multicolumn{2}{c}{ Subsidized } \\
\cline { 2 - 5 } & $\begin{array}{c}\text { Amount } \\
\text { (Liters) }\end{array}$ & Value & $\begin{array}{r}\text { Amount } \\
\text { (Liters) }\end{array}$ & Value \\
\hline Postin & 1.31 & 85,107 & 1.29 & 83,921 \\
Skor & 2.19 & 327,845 & 1.02 & 153,631 \\
Virtako & 0.70 & 143,095 & 0.74 & 151,310 \\
Topshot & 2.45 & 207,990 & 1.74 & 148,296 \\
\hline Amount & & $\mathbf{7 6 4 , 0 3 7}$ & & $\mathbf{5 3 7 , 1 5 7}$ \\
\hline
\end{tabular}

Farmers who use non-subsidized seeds commonly use more pesticides to prevent pests, diseases and weeds because there are several rice varieties that require special care, especially Skor and Topsol pesticide. The total cost of pesticide use of subsidized seeds is greater than that of the non-subsidized. This is because thesubsidized seed pests are greater than that of the subsidized. Subsidized rice seeds are more resistant to pests and diseases.

Furthermore, labor costs are comprised of of family labor costs (TKDK) and out-of-family labor costs/hired labor cost (TKLK). Family labor (TKDK) employs workers who are members of the farming family. Out-of-family labor costs (TKLK) employ hired workers who are not the member of the farming family. Labor costs of non-subsidized seeds are greater than those of subsidized seeds. This is because of the higher volume of work in farming for non-subsidized seeds.

Rice farming needs to use equipment to support land processing and maintenance activities in rice plants both by using non-subsidized rice seeds and subsidizing. Some used agricultural equipments are hoes, sickles, sprays and buckets. Every year there has been a decline in the use of agricultural equipment due to use. The hoe is used to cultivate the land, such as making a hole in the paddy field. Sickle is used to cut grass or weeds that disturb the growth of rice plants besides that crescent is also used by farmers to harvest rice. Spray or hand spayers are used by farmers to spray pesticides such as pests and weeds that disturb rice plants. There are manual hand sprayers owned by various farmers and there are already small machines fueled by gasoline. Buckets are used by farmers as fertilizer containers during fertilization.

The cost of depreciation of agricultural equipment with non-subsidized seeds is higher than that of subsidized rice seeds, because most farmers who use non-subsidized seeds use hand sprayer machines that have high depreciation costs. The average price of a machine handspayer is $\mathrm{Rp} \mathrm{1,200,000}$ - Rp 1,500,000. Farmers prefer using a machine hand sprayer because it is easier to operate and more energy saving than manual hand sprayers.

Other costs consist of building tax costs, electricity costs and land rent. The building tax costs on rice farming with many subsidized seeds are higher than farmers who use nonsubsidized seeds. Farmers who use subsidized seeds are required to irrigate more often because of the various types of subsidized rice variety, including Ciherang variety that requires more water and regular irrigation, and subsequently leads to an increase of electricity costs. The cost for land rent in Sekarputih Village of $1 \mathrm{Ha}$ with 3-time planting seasons is $\operatorname{Rp} 20,000,000$ per year. Thus, 1 planting season of rent land cost about Rp 6,666,667.

Explicit costs are costs that are actually incurred by farmers to conduct farming. Explicit costs include the cost of seeds, fertilizers, pesticides, depreciation of equipment, labor outside the family and other costs consisting of building tax costs and electricity costs incurred.

Seed costs are higher because of the use of more seeds, even though the price of non-subsidized seeds is higher. Farmers are not interested in using subsidized seeds even though the price is cheaper. Judging from the overall costs, the cost of seeds is constituted of a very small percentage $(4.29 \%$ of non-subsidized seeds and $1.05 \%$ of seed subsidized), thus, usually it is not something to be considered by farmers in choosing seed prices. According to [4], the difference in price and quality of seed subsidized and non-subsidized are not that much different,making farmers reluctant to use subsidized seeds. Subsidized rice seed farmers have lower explicit costs because the amount of input used is lower. Explicit costs of rice farming with nonsubsidized and subsidized rice seeds in Sekarputih village can be seen in Table 3 .

Table 3. The explisits cost on Rice farming with nonsubsidized and subsidized seed per 1 hectar

\begin{tabular}{|c|c|c|c|c|}
\hline \multirow[t]{2}{*}{ Description } & \multirow{2}{*}{$\begin{array}{r}\text { Non- } \\
\text { Subsidized } \\
\text { Cost }(\mathbf{R p})\end{array}$} & \multirow{2}{*}{$\begin{array}{c}\text { Percentage } \\
(\%)\end{array}$} & \multirow{2}{*}{$\begin{array}{r}\text { Subsidized } \\
\text { Cost (Rp) } \\
\end{array}$} & \multirow{2}{*}{$\begin{array}{l}\text { Percentage } \\
(\%)\end{array}$} \\
\hline & & & & \\
\hline 1. Seed & 385,429 & 4.29 & 88,521 & 1.05 \\
\hline \multicolumn{5}{|l|}{2 Fertilizer } \\
\hline a. Phonska & 981,965 & 10.93 & $1,215,007$ & 14.51 \\
\hline b. SP36 & 219,056 & 2.44 & 240,472 & 2.87 \\
\hline c. Urea & 808,499 & 9.00 & 598,040 & 7.14 \\
\hline d. ZA & 309,277 & 3.44 & 273,143 & 3.26 \\
\hline \multicolumn{5}{|l|}{ 3. Pesticide } \\
\hline a. Postin & 85,107 & 0.95 & 83,921 & 1.00 \\
\hline b. Skor & 327,845 & 3.65 & 153,631 & 1.84 \\
\hline c. Virtako & 143,095 & 1.59 & 151,310 & 1.81 \\
\hline d. Topshot & 207,990 & 2.32 & 148,296 & 1.77 \\
\hline $\begin{array}{l}4 . \\
\text { Depresiation }\end{array}$ & 32,809 & 0.37 & 15,347 & 0.18 \\
\hline $\begin{array}{l}\text { 5. Out } \\
\text { Labour }\end{array}$ & $3,861,147$ & 42.98 & $2,937,203$ & 35.08 \\
\hline $\begin{array}{l}\text { 6. Other } \\
\text { Costs }\end{array}$ & $1,620,602$ & 18.04 & $2,467,555$ & 29.47 \\
\hline Total & $8,982,821$ & 100 & $8,372,176$ & 100 \\
\hline
\end{tabular}


The cost of outside family labor/hired labor (TKLK) and other costs consisting of tax costs, land rent and electricity costs constitute as the highest cost.

Implicit costs are costs that are not significantly incurred by farmers such as labor in the family and the cost of leasing their own land. Implicit costs are calculated to determine the benefits of non-subsidized and subsidized rice farming. Implicit costs include labor costs in the family, ownership of capital interest and the cost of leasing the land. The implicit total cost can be seen in Table 4 .

Table 4. The Implicit cost on rice farming with nonsubsidized and subsidized seed per 1 hectar

\begin{tabular}{lrr}
\hline \multirow{2}{*}{ Description } & Non-Subsidized & Subsidized \\
\cline { 2 - 3 } & Cost (Rp) & Cost (Rp) \\
\hline Interest of own capital & 259,048 & 250,618 \\
Rent of own land & $6,250,000$ & $5,555,556$ \\
Family Labour & 786,508 & 562,421 \\
\hline Total & $\mathbf{7 , 3 0 5 , 9 9 3}$ & $\mathbf{6 , 3 6 9 , 1 4 2}$ \\
\hline
\end{tabular}

The implicit cost is greater in non-subsidized seed rice farming. The highest cost in rice farming with nonsubsidized seeds or subsidized seeds is the value of own land rent. The rent value of own land is costly because the farmers in Sekarputih Village are very enthusiastic to work on the land, so there is a struggle over the land if someone rents out. This makes the cost of leasing land in Sekarputih Village high.

Farming acceptance is the result of multiplication between rice production and the price of unhulled rice. Rice Farming Revenue with Non-Subsidized Seeds and Subsidized is presented in Table 5.

Table 5. Revenue on rice farming with non-subsidized and subsidized seed per 1 hectar

\begin{tabular}{lrrrr}
\hline & \multicolumn{2}{c}{ Non-Subsidized } & Subsidized \\
\cline { 2 - 5 } Description & $\begin{array}{r}\text { Amount } \\
(\mathrm{Kg})\end{array}$ & $\begin{array}{r}\text { Price } \\
(\mathrm{Rp})\end{array}$ & $\begin{array}{r}\text { Amount } \\
(\mathrm{Kg})\end{array}$ & $\begin{array}{r}\text { Price } \\
(\mathrm{Rp})\end{array}$ \\
\hline $\begin{array}{l}\text { Dry Grain } \\
\text { Harvest }\end{array}$ & 6,594 & 4,196 & 5,907 & 4,184 \\
\hline Total & \multicolumn{2}{c}{$27,668,424$} & & $24,714,888$ \\
\hline
\end{tabular}

The income received by farmers with non-subsidized seeds is higher than those with subsidized seeds. One of the factors that influence the income in rice farming is the amount of rice production. Rice productivity with nonsubsidized seeds is higher than that using subsidized seeds.

Farming income is the difference between the revenue and the explicit total costs. Rice farming income of both nonsubsidized seeds and subsidized can be seen in Table 6 .

Table 6. Income on rice farming with non-subsidized and subsidized seed per 1 hectar

\begin{tabular}{lrr}
\hline Description & Non-Subsidized & Subsidized \\
\hline Revenue & $27,668,424$ & $24,714,888$ \\
Explicits Total Cost & $8,982,821$ & $8,372,176$ \\
\hline Total & $\mathbf{1 8 , 6 8 5 , 6 0 3}$ & $\mathbf{1 6 , 3 4 2 , 7 1 2}$ \\
\hline
\end{tabular}

Rice farming income of non-subsidized rice seeds is higher than rice farming with subsidized seeds. The high income in farming with non-subsidized seeds is because the difference in revenue is greater than the difference in explicit costs, which means that the difference in the value of the productivity of non-subsidized seed farming is greater than the difference in cost. The income of rice with nonsubsidized seeds and subsidized seeds in Ngawi Regency is Rp18,685,603,-/Ha and Rp 16,342,712, - / Ha. When compared to other regions, the rice income in Ngawi Regency is still higher than that of other regions. According to Kaninu, F.G's (2016), the rice income in Parigi District was only Rp 5,792,295 / Ha, with R / C of 1.84. Likewise, [5] reveals the same thing, in that rice farming income of the Jajar Legowo pattern in Morowali District, Central Sulawesi, only amounted to Rp 8,767,000 / Ha.

For farmers, the most important thing is having a great income. Despite the higher production costs because of the rarity of subsidized seeds and the great cost of pesticide use, they opted to choose higher production since it causes greater income. Then, the government increasing production becomes important for meeting the needs of rice in the country. Resistance to pest attacks is also important so that farmers do not use pesticides that can damage the environment. Moreover, environmental issues have become a global interest, so that healthy food leads to organic food, whose production is not polluted by unhealthy environments such as land contamination by pesticide residues.

In cultivating rice farming, profit is the goal in conducting farming. Farmers must reduce input costs to get the maximum profit from rice production [6]. Profits in farming represent the difference between income and implicit costs. Benefits of rice farming with non-subsidized seeds and subsidized can be seen in Table 7 .

Table 7. Profit on rice farming with non-subsidized and subsidized seed per 1 hectar

\begin{tabular}{lrr}
\hline & Non-Subsidized & Subsidized \\
\hline Revenue & $27,668,424$ & $24,714,888$ \\
Total Cost & $16,288,814$ & $14,741,318$ \\
\hline Profit & $\mathbf{1 1 , 3 7 9 , 6 1 0}$ & $\mathbf{9 , 9 7 3 , 5 7 0}$ \\
\hline
\end{tabular}

$\mathrm{R} / \mathrm{C}$ analysis is the ratio used to see the relative benefits resulted in rice farming. $\mathrm{R} / \mathrm{C}$ of rice farming with nonsubsidized seeds is higher than that of subsidized seeds. This is in line with the research by [7] which states that $\mathrm{R} / \mathrm{C}$ in rice business uses non-certified seeds 4.41 , while those using 2.51 are certified rice seeds. The certified seeds lead to no better result than non-certified seeds. The use of noncertified seeds is more profitable, as asserted by [8]. Conversely, the $\mathrm{R}$ / C results show the opposite, where $\mathrm{R} / \mathrm{C}$ from farming using certified rice seeds is higher than noncertified seed yields.

Capital productivity in rice farming is the ability of farmers to return the capital used to carry out rice farming which is expressed in percent (\%). The capital productivity of each farm's, greater than the bank interest rate in the study area, is $3 \%$ during one growing season. 
Land productivity is the ability of land to produce rice farming that uses non-subsidized and subsidized seeds which are expressed in the form of Rupiah ( $\mathrm{Rp})$. Productivity in both farms is feasible because it is larger than the land rent in Sekarputih village which is Rp 666.67 per meter in each season.

Labor productivity is the ability of the family workforce to get income, expressed in Rp / HKO. Labor productivity is higher in farms that use non-subsidized seeds. Thus, both are feasible because they are greater than the minimum wage applicable in the local area, which is Rp 75,000 for land processing with hoes, Rp 50,000 for planting and Rp30,000 for the maintenance of rice plants.

Table 8. showed the results of feasibility consisting of R/ C, Capital Productivity, Land Productivity, Labor Productivity.

Table 8 . Feasibility on rice farming with non-subsidized and subsidized seed per 1 hectar

\begin{tabular}{lrr}
\hline & Non-Subsidized & Subsidized \\
\hline Revenue & $27,668,424$ & $24,714,888$ \\
Total Cost & $16,288,814$ & $14,741,318$ \\
\hline R/C & $\mathbf{1 . 7 0}$ & $\mathbf{1 . 6 8}$ \\
\hline Income & $18,688,329$ & $16,341,158$ \\
\hline Rent of own land & $6,250,000$ & $5,555,556$ \\
\hline Family labour & 786,508 & 562,421 \\
\hline Total explicit cot & $8,982,821$ & $8,372,176$ \\
\hline Capital productivity & $\mathbf{1 2 9 . 7 1}$ & $\mathbf{1 2 2 . 1 1}$ \\
\hline Income & $18,688,424$ & $16,341,158$ \\
\hline Family labour & 786,508 & 562,421 \\
\hline Interest of own capital & 269,485 & 251,165 \\
\hline Area of land & 10,000 & 10,000 \\
\hline Land productivity (Rp) & $\mathbf{1 7 , 6 3 0 , 0 0 0}$ & $\mathbf{1 5 , 5 3 0 , 0 0 0}$ \\
\hline Income & $18,688,424$ & $16,341,158$ \\
\hline Rent of own land & $6,250,000$ & $5,555,556$ \\
\hline Interest of own capital & 269,485 & 251,165 \\
\hline Family labour & 17.88 & 11.08 \\
\hline Labour productivity (Rp) & $\mathbf{6 8 0 , 4 0 7}$ & $\mathbf{9 5 0 , 3 6 8}$ \\
\hline & & \\
\hline
\end{tabular}

\section{CONCLUSION}

Rice farming costs of non-subsidized seeds of $\mathrm{Rp}$ $16,288,814$ is greater than the cost of farming of the subsidized seeds, namely amounting to $\mathrm{Rp} 14,741,318$. Farming income non-subsidized rice seeds amounting to Rp $18,688,329$ are greater than that of subsidized seeds, namely $\mathrm{Rp} 16,341,158$ Advantages of rice farming with nonsubsidized seeds Rp 11,382,335, greater than farming profits by using subsidized seeds, which is $\mathrm{Rp} 9,990,015$. Feasibility with R / C on non-subsidized seeds is 1.70 and a subsidized seed is 1.68 which means that the farming is feasible to cultivate. Land productivity in rice farming with non-subsidized seeds is $\mathrm{Rp} 17,630,000$ per hectare for each planting season, whilethe subsidized rice seeds amounting to Rp 15,530,000 per hectare for every planting season are classified as feasible. Labor productivity in farming with non-subsidized seeds amounted to Rp 680,407 / HKO and that of farmers who use subsidized rice seeds amounted to Rp 950,386 / HKO. Thus, it is conclusive that both are worthy of effort.

The differences between the interests of farmers as the producer and the owner of factors of production with the interests of the government as the policy taker need to put together on a portion of a design so that all interests can be implemented. Increasing cultivate plants especially for rice plants to find the good varieties and higher productivity.

\section{ACKNOWLEDGMENT}

The researchers would like to exert gratitude to the University of Muhammadiyah Yogyakarta for providing the opportunity to participate in a partnership research program managed by LP3M UMY. The researcher also expressed gratitude to the Muhammadiyah University of Yogyakarta for providing financial assistance for the research implementation.

\section{REFERENCES}

[1] Sugiyono. Metode Penelitian Kuantitatif Kualitatif dan $R \& D$. Bandung: Alfabeta, 2016.

[2] H. Umar. Metode penelitian untuk skripsi dan tesis bisnis. Jakarta: PT Rajagrafindo Persada, 2005

[3] M. Supartama, A. Made and A.R. Rustam. "Analisis Pendapatan dan Kelayakan Usahatani Padi Sawah di Subak Baturiti Desa Balinggi Kecamatan Balinggi Kabupaten Parigi Moutong”. Agrotekbis. vol. 1, pp. 166-172, 2013.

[4] Bappenas. (2011, Feb.). "Laporan Kajian Strategi Oleh Kementrian Perencanaan Pembanguanan Nasional”. Kajian Biro Hukum. [Online]. Available: www.birohukum.bappenas.goid [March, 2017].

[5] P.A Suwardana, A. Made and N.A. Max. "Analisis Produksi dan Pendapatan Usahatani Padi Sawah dengan Pola Jajar Legowo di Desa Laantula Jaya Kecamatan Witaponda Kabupaten Morowali”. Agrotekbis, vol. 1, pp. 477-484, 2013.

[6] H.V. Tu and N.T Trang. "Cost Efficiency of Rice Production in Vietnam: An Aplication of Stochastic Translog Variable Cost Frontier". Asian Journal of Aricultural Extension, Economics and Sociology. vol. 8, pp. 1-10, 2016.

[7] A. Rizky. "Analisis Produktivitas Padi dengan Menggunakan Benih Sertifikat dan Benih Non Sertifikat di Kecamatan Banyubiru Kabupaten Semarang". EDAJ, vol. 1, 2012.

[8] R. Raditya, S. A. Putri, and Sriyoto. "Analisis Komparasi Usahatani Padi Sawah Pengguna Benih Bersertifikat dan Benih Non Sertifikat di Kelurahan Kemumu Kecamatan Arma Jaya Kabupaten Bengkulu Utara”. Agrisep. vol. 15, pp. 177-186, 2015. 